OPEN

SUBJECT AREAS:

NANOSENSORS

SENSORS

Received

17 December 2013

Accepted

20 January 2014

Published

5 February 2014

Correspondence and requests for materials should be addressed to Z.L.J. (zlijiang@ mailbox.gxnu.edu.cn) or A.H.L. (ahliang2008@163. com)

\section{Autocatalytic Oxidization of Nanosilver and Its Application to Spectral Analysis}

\author{
Guiqing Wen, Yanghe Luo, Aihui Liang \& Zhiliang Jiang
}

Key Laboratory of Ecology of Rare and Endangered Species and Environmental Protection of Ministry Education, Guangxi Normal University, Guilin 541004, China.

The stable yellow nanosilver (AgNP) and blue nanosilver (AgNPB) sols were prepared by the $\mathrm{NaBH}_{4}$ procedure. The new nanocatalytic reaction of AgNP-NaCl- $\mathrm{H}_{2} \mathrm{O}_{2}$ was investigated by surface plasmon resonance (SPR) absorption, resonance Rayleigh scattering (RRS), surface-enhanced Raman scattering (SERS) and scanning electron microscope (SEM) techniques. The autocatalytic oxidization of Ag on AgNP

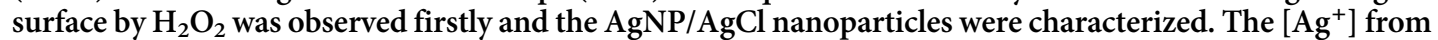
$\mathrm{AgNP}$ is different to the $\mathrm{Ag}^{+}$from $\mathrm{AgNO}_{3}$ that adsorb on the AgNP surface. An autocatalytic oxidization mechanism was proposed to explain experimental phenomena. The relationship between the SPR absorption peaks and the RRS peaks of AgNPB was studied, and three characteristic RRS peaks called as out-of-plane quadrupole, out-of-plane dipole and in-plane dipole RRS peaks were observed firstly. Using AgNP as nanoprobe, a simple, sensitive and selective RRS method was developed for assay of $\mathrm{H}_{2} \mathrm{O}_{2}$ in the range of $2.0 \times 10^{-8}-8.0 \times 10^{-5} \mathrm{~mol} / \mathrm{L}$.

N anoparticles have become research hot-spot in subjects such as physics, chemistry and materials due to their unique physical and chemical properties ${ }^{1-5}$. Based on the optical properties of nanoparticles, some new types of optical sensors and optoelectronic devices have been developed ${ }^{6-9}$. And the research of nanocatalysis and its application has become the important research directions in catalytic synthesis and nanoanalysis $^{10-16}$. Among the nanocatalysis, the reports were mainly about nanogold catalysis and nano titanium dioxide photocatalysis ${ }^{17-19}$. Recently, some new nanocatalytic analytical methods were established ${ }^{20-25}$, based on the catalysis of nanogold on the $\mathrm{Cu}$ (II)-glucose, $\mathrm{HAuCl}_{4}$-ascrobic, $\mathrm{HAuCl}_{4}$-citrate, $\mathrm{Te}(\mathrm{IV})$ - $\mathrm{Sn}$ (II), phosphomolybdic acid-formic acid and $\mathrm{Ag}(\mathrm{I})$-hydroquinone particle reactions. It is rare report about nanosilver catalytic reaction. In synthesis of triangular nanosilver ${ }^{26,27}$, the catalysis of nanosilver has been observed. Nanosilver modified by aptamer exhibited strong catalysis of the $\mathrm{Cu}_{2} \mathrm{O}$ particle reaction of Fehling reagent-glucose, and it has been used to determine trace melamine by RRS technique ${ }^{28}$. Up to date, the autocatalytic oxidization of AgNP and its application in trace $\mathrm{H}_{2} \mathrm{O}_{2}$ analysis have not been reported.

The content of $\mathrm{H}_{2} \mathrm{O}_{2}$ is closely related to the photochemical reactions, oxidation-reduction reactions in natural water bodies. It is one of the important factors to affect the transfer, transformation, and ecological effect of chemical substances in water, and it is also one of the main reasons in the formation of acid rain ${ }^{29}$. In addition, the detection of $\mathrm{H}_{2} \mathrm{O}_{2}$ content is also very important in biochemical reactions, clinical test, food safety, and other fields ${ }^{20-32}$. At present, the spectral methods for $\mathrm{H}_{2} \mathrm{O}_{2}$ content are mainly including chemiluminescence, fluorescence, spectrophotometry, etc ${ }^{33-35}$. Among them, spectrophotometry is commonly used for its simple operation and low-cost. Recently, stabile metal nanoparticles, especially nanogold and nanosilver, are interesting to analyst. The spectral probe, based on nanogold color and RRS, have been used for determination of tumor markers, $\mathrm{Hg}^{2+}$, $\mathrm{H}_{2} \mathrm{O}_{2}, \mathrm{HCl}$ and so on ${ }^{36-41}$. Compare to nanogold, AgNP has the advantage of low cost, and its aggregates do not interfere to the absorbance measurement since its absorption is very weak. In addition, stabile AgNP can be prepared by modern synthesis procedure and it has become novel spectral probe due to its strong SPR absorption, strong RRS and SERS effects of its aggregates ${ }^{42}$. It has been utilized to colorimetric chiral recognition of enantiomers, detection of DNA and melamine etc ${ }^{28,43-45}$. However, there is no report about the research and application of AgNP-NaCl- $\mathrm{H}_{2} \mathrm{O}_{2}$ autonanocatalytic system yet. In this paper, the reaction mechanism of AgNP-NaCl- $\mathrm{H}_{2} \mathrm{O}_{2}$ was studied by SPR, RRS ${ }^{46-48}$, SERS and SEM techniques. Thus, two simple, rapid and sensitive spectral methods have been developed to determine $\mathrm{H}_{2} \mathrm{O}_{2}$.

\section{Results}

Scanning electron microscope. Stabile AgNP sol was prepared by $\mathrm{NaBH}_{4}$ reduction of $\mathrm{AgNO}_{3}$ in the presence of citrate. The SEM shows that they are spherical, with average size of $10 \pm 2 \mathrm{~nm}$ (Fig. 1a). In AgNP-NaCl- $\mathrm{H}_{2} \mathrm{O}_{2}$ 

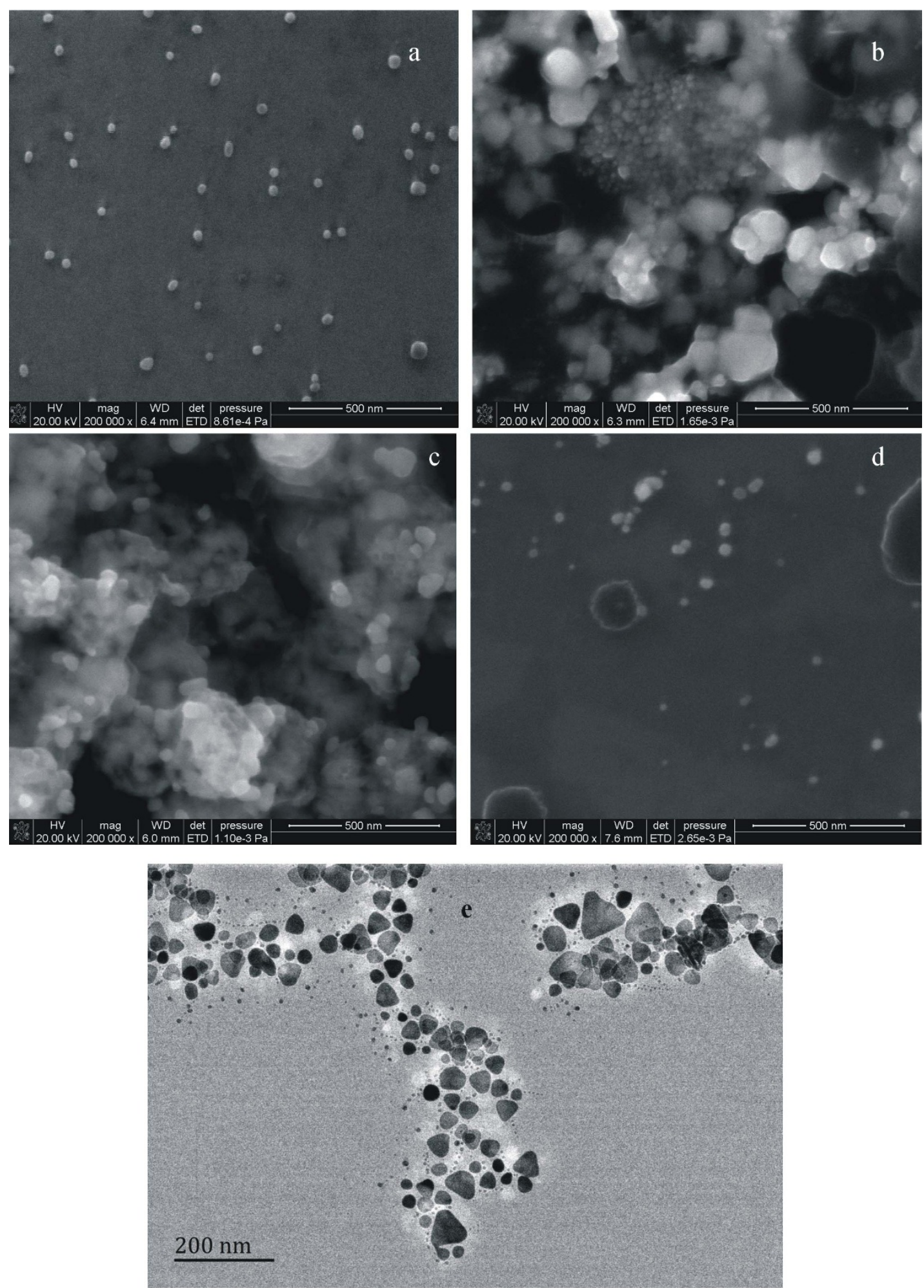

Figure 1 SEM (a-d) and TEM (e) of AgNP. (a): $9.25 \times 10^{-5} \mathrm{~mol} / \mathrm{L} \mathrm{AgNP}$; (b):9.25 $\times 10^{-5} \mathrm{~mol} / \mathrm{L} \mathrm{AgNP}-2.0 \times 10^{-3} \mathrm{~mol} / \mathrm{L} \mathrm{NaCl}-20 \times 10^{-5} \mathrm{~mol} / \mathrm{L}$ $\mathrm{H}_{2} \mathrm{O}_{2} ;(\mathrm{c}): 9.25 \times 10^{-5} \mathrm{~mol} / \mathrm{L}$ AgNP-2.0 $\times 10^{-3} \mathrm{~mol} / \mathrm{L} \mathrm{H}_{2} \mathrm{SO}_{4}-2.0 \times 10^{-3} \mathrm{~mol} / \mathrm{L} \mathrm{NaCl}-3.75 \times 10^{-5} \mathrm{~mol} / \mathrm{L} \mathrm{FeSO}_{4}-1.5 \times 10^{-5} \mathrm{~mol} / \mathrm{L} \mathrm{H}_{2} \mathrm{O}_{2} ;(\mathrm{d}): 5.0 \times$ $10^{-5} \mathrm{~mol} / \mathrm{L}$ AgNPB; (e): $5.0 \times 10^{-5} \mathrm{~mol} / \mathrm{L}$ AgNPB.

system, there is an autocatalytic oxidation reaction on the surface of AgNP to generate large $\mathrm{Ag}_{\mathrm{n}} / \mathrm{AgCl}$ particles with an average size of 60 $\pm 15 \mathrm{~nm}$ (Fig. 1b). In AgNP- $\mathrm{H}_{2} \mathrm{SO}_{4}-\mathrm{NaCl}-\mathrm{FeSO}_{4}-\mathrm{H}_{2} \mathrm{O}_{2}$ system, on one hand the autocatalytic oxidation reaction of $\mathrm{AgNP}$ generate $\mathrm{Ag}^{+}$ on the surface, on the other hand surface atoms of AgNP also can generate $\mathrm{Ag}^{+}$by the Fenton oxidation reaction, so the large $\mathrm{Ag}_{\mathrm{n}} / \mathrm{AgCl}$ particles with an average size of $75 \pm 16 \mathrm{~nm}$ was formed (Fig. 1c).
SEM of AgNPB system shows that they are nearly spherical, with particle size between 6-100 $\mathrm{nm}$ and an average size of $40 \pm 8 \mathrm{~nm}$ (Fig. 1d). The shape of AgNPB can not be observed satisfactorily by SEM, and the TEM of AgNPB system was done. Figure 2e indicated that there triangle nanosilver particles in the system, with the side length between 30-90 nm and an average side length of $45 \pm 10 \mathrm{~nm}$, in addition to the nearly spherical particles. 

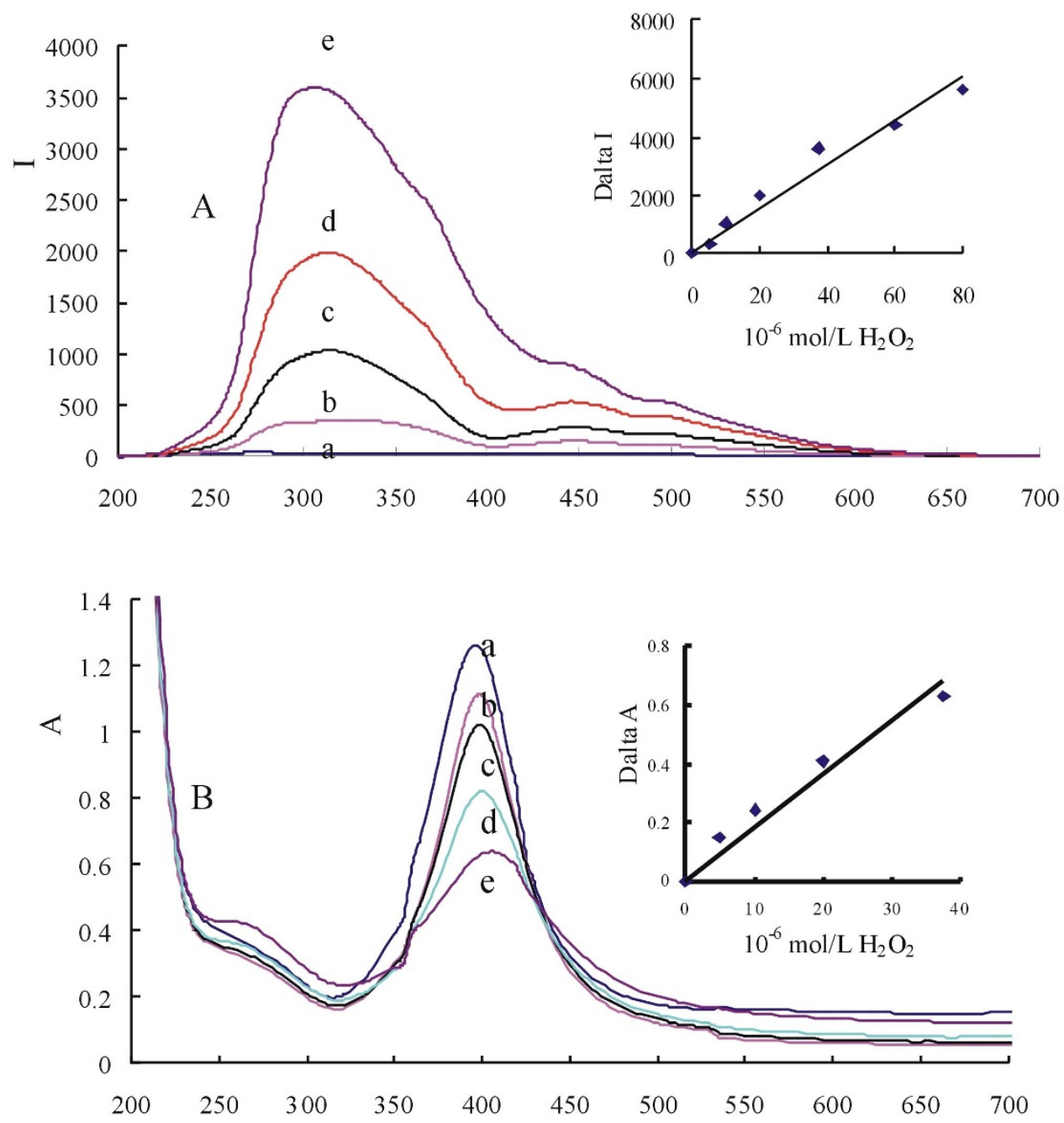

Figure $2 \mid \mathrm{RRS}(\mathrm{A})$ and SPR (B) spectra of AgNP-NaCl- $\mathrm{H}_{2} \mathrm{O}_{2}$ system. (a): $9.25 \times 10^{-5} \mathrm{~mol} / \mathrm{L} \mathrm{AgNP}-2.0 \times 10^{-3} \mathrm{~mol} / \mathrm{L} \mathrm{NaCl} ;(\mathrm{b}): \mathrm{a}-5.0 \times 10^{-6} \mathrm{~mol} / \mathrm{L}$ $\mathrm{H}_{2} \mathrm{O}_{2} ;(\mathrm{c}): \mathrm{a}-1.0 \times 10^{-5} \mathrm{~mol} / \mathrm{L} \mathrm{H}_{2} \mathrm{O}_{2} ;(\mathrm{d}): \mathrm{a}-2.0 \times 10^{-5} \mathrm{~mol} / \mathrm{L} \mathrm{H}_{2} \mathrm{O}_{2} ;(\mathrm{e}): \mathrm{a}-5.0 \times 10^{-5} \mathrm{~mol} / \mathrm{L} \mathrm{H}_{2} \mathrm{O}_{2}$.

RRS spectra. In $2.0 \times 10^{-3} \mathrm{~mol} / \mathrm{L} \mathrm{NaCl}$ medium, AgNPs are stabile and its RRS signal is very weak (Fig. 2A). With addition of $\mathrm{H}_{2} \mathrm{O}_{2}$, AgNP catalyze $\mathrm{H}_{2} \mathrm{O}_{2}$ to produce $\mathrm{HO} \cdot$ and oxidize $\mathrm{Ag}$ atoms on the surface of AgNP to produce $\left[\mathrm{Ag}^{+}\right]$. The $\left[\mathrm{Ag}^{+}\right]$combined with $\mathrm{Cl}^{-}$to form $[\mathrm{AgCl}]$ with strong hydrophobicity and then lead to form larger $\mathrm{AgNP} / \mathrm{AgCl}$ aggregates that obviously enhanced the RRS intensity at $330 \mathrm{~nm}, 460 \mathrm{~nm}$ and $500 \mathrm{~nm}$. The most sensitive RRS peak at $330 \mathrm{~nm}$ was selected to use in this paper. In existence of $\mathrm{Fe}(\mathrm{II})$ and $\mathrm{H}_{2} \mathrm{SO}_{4}$, the system had four RRS peaks at $290 \mathrm{~nm}, 360 \mathrm{~nm}, 455 \mathrm{~nm}$ and $500 \mathrm{~nm}$ (Fig. 1S). Fe(II) can hydrolyze and cause weak aggregation of AgNPs, and the blank increased. When adding $\mathrm{H}_{2} \mathrm{O}_{2}$, the Fenton reaction $\left(\mathrm{FeSO}_{4}-\mathrm{H}_{2} \mathrm{O}_{2}\right)$ also produced $\mathrm{HO} \cdot$ that oxidize AgNP to form $\left[\mathrm{Ag}^{+}\right]$and $\mathrm{AgNP} /[\mathrm{AgCl}]$ particles. With $\mathrm{H}_{2} \mathrm{O}_{2}$ concentration increase its peak enhanced linearly due to more particles forming.

With addition of different concentration of $\mathrm{AgNO}_{3}$ to the system of $2.0 \times 10^{-3} \mathrm{~mol} / \mathrm{L} \mathrm{NaCl}-0.035 \%$ sodium citrate, $\mathrm{AgCl}$ particles were generated and exhibited strong scattering signal at $335 \mathrm{~nm}$ (Fig. 2S). The increased intensity $\Delta I_{335 \mathrm{~nm}}$ was linear to $\mathrm{AgNO}_{3}$ concentration in the range of $12.5-100 \times 10^{-6} \mathrm{~mol} / \mathrm{L}$ with the regression equation of $\Delta I_{335 \mathrm{~nm}}=53.3 \mathrm{c}_{\mathrm{Ag}+}-93$. For the system of $2.0 \times$ $10^{-3} \mathrm{~mol} / \mathrm{L} \mathrm{NaCl}-0.035 \%$ sodium citrate- $2.0 \times 10^{-3} \mathrm{~mol} / \mathrm{L} \mathrm{H}_{2} \mathrm{SO}_{4^{-}}$ $3.75 \times 10^{-5} \mathrm{~mol} / \mathrm{L} \mathrm{FeSO}_{4}-\mathrm{AgNO}_{3}, \mathrm{AgCl}$ particles exhibited strong scattering signal at $335 \mathrm{~nm}$ (Fig. 3S). The increased intensity $\Delta I_{335} \mathrm{~nm}$ was linear to $\mathrm{AgNO}_{3}$ concentration in the range of 12.5-100 $\times$ $10^{-6} \mathrm{~mol} / \mathrm{L}$ with the regression equation of $\Delta I_{335 \mathrm{~nm}}=51.0 \mathrm{c}_{\mathrm{Ag}+}+$
116. This suggests that RRS signal's enhancement of AgNP-NaCl$\mathrm{H}_{2} \mathrm{O}_{2}$ system is the result of the formation of $\mathrm{AgCl}$ particles. When adding different concentration of $\mathrm{Ag}^{+}$to the AgNP-NaCl-sodium citrate system, the RRS spectrum (Fig. 4S) is different with that of AgNP-NaCl- $\mathrm{H}_{2} \mathrm{O}_{2}$ and the former is weaker. It also suggests that $\left[\mathrm{Ag}^{+}\right]$which produced by AgNP surface oxidation is different with that adsorption on the surface of the AgNP by adding $\mathrm{AgNO}_{3}$. Compare to RRS spectra of $\mathrm{NaCl}$-sodium citrate- $\mathrm{AgNO}_{3}$ system, the RRS intensity of $\mathrm{AgNP}-\mathrm{NaCl}$-sodium citrate system is greatly reduced and has a valley at $395 \mathrm{~nm}$, as the result of the strongest absorption of AgNPs at $395 \mathrm{~nm}$.

SPR absorption spectra. Mie theory ${ }^{49}$ pointed out that, spherical nanoparticles have only one SPR absorption peak. Spherical AgNP with diameter of 20-30 nm has the strongest SPR peak near $400 \mathrm{~nm}^{50}$, which is out-of-plane dipole SPR absorption peak ${ }^{51}$. In the systems of $\mathrm{NaCl}$ and $\mathrm{NaCl}-\mathrm{H}_{2} \mathrm{SO}_{4}-\mathrm{FeSO}_{4}$, both have an AgNP SPR absorption peak at $395 \mathrm{~nm}$ (Fig. 2B, Fig. 5S). The absorbance at $395 \mathrm{~nm}$ of the two systems decreased linearly with the $\mathrm{H}_{2} \mathrm{O}_{2}$ concentration increased and can be chosen to determine $\mathrm{H}_{2} \mathrm{O}_{2}$. The $\mathrm{AgNO}_{3}-\mathrm{NaCl}$ and $\mathrm{AgNO}_{3}-\mathrm{NaCl}-\mathrm{H}_{2} \mathrm{SO}_{4}-\mathrm{FeSO}_{4}$ systems were examined by spectrophotometry. With addition of different $\mathrm{AgNO}_{3}$ concentration to the two systems of $2.0 \times 10^{-3} \mathrm{~mol} / \mathrm{L}$ $\mathrm{NaCl}-0.035 \%$ sodium citrate and $2.0 \times 10^{-3} \mathrm{~mol} / \mathrm{L} \mathrm{NaCl}-0.035 \%$ sodium citrate $-2.0 \times 10^{-3} \mathrm{~mol} / \mathrm{L} \mathrm{H}_{2} \mathrm{SO}_{4}-3.75 \times 10^{-5} \mathrm{~mol} / \mathrm{L}$ $\mathrm{FeSO}_{4}$, the produced $\mathrm{AgCl}$ particles exhibited weak SPR peak at 


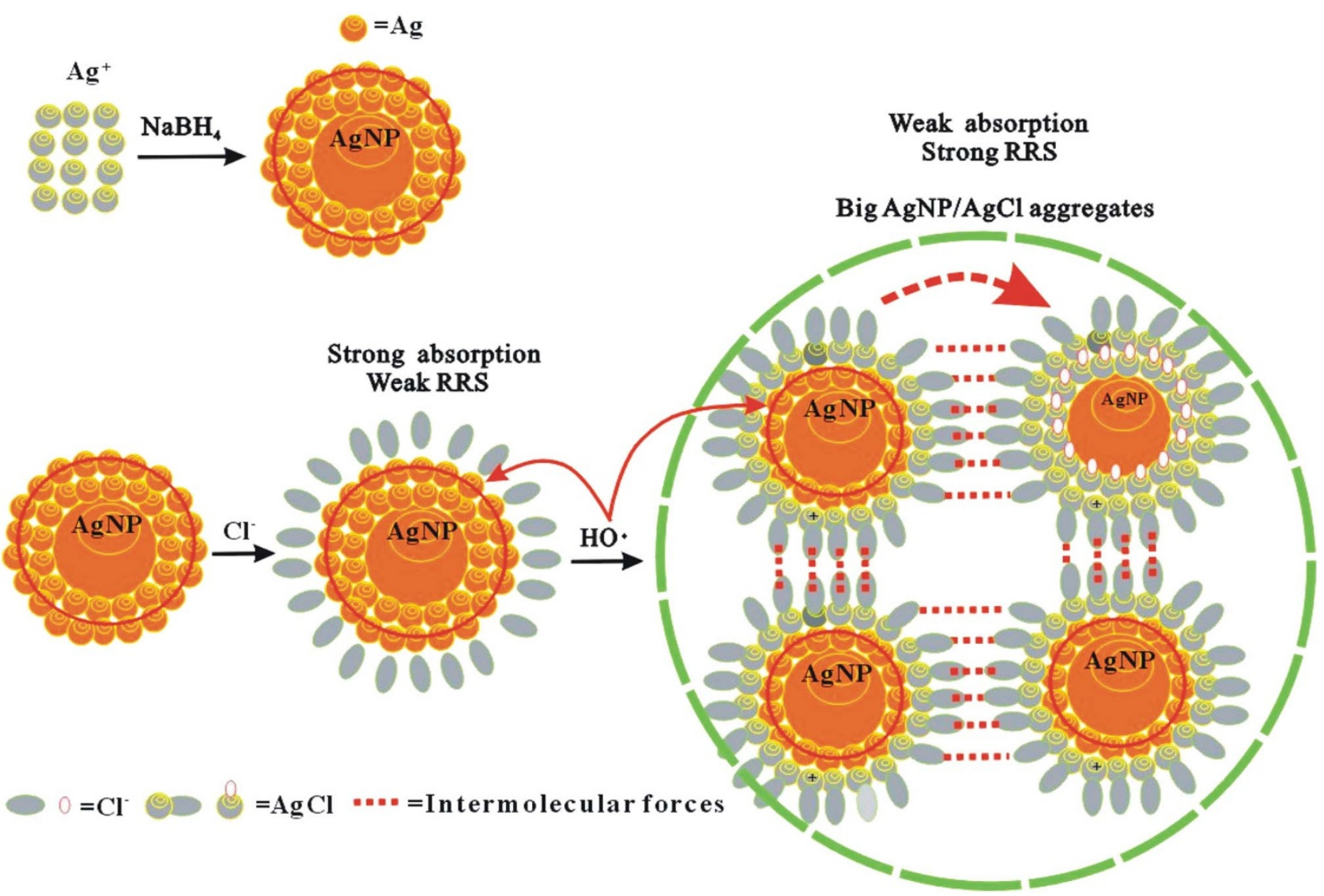

Figure 3 Principle of autocatalytic oxidization of AgNP to detect $\mathrm{H}_{2} \mathrm{O}_{2}$.
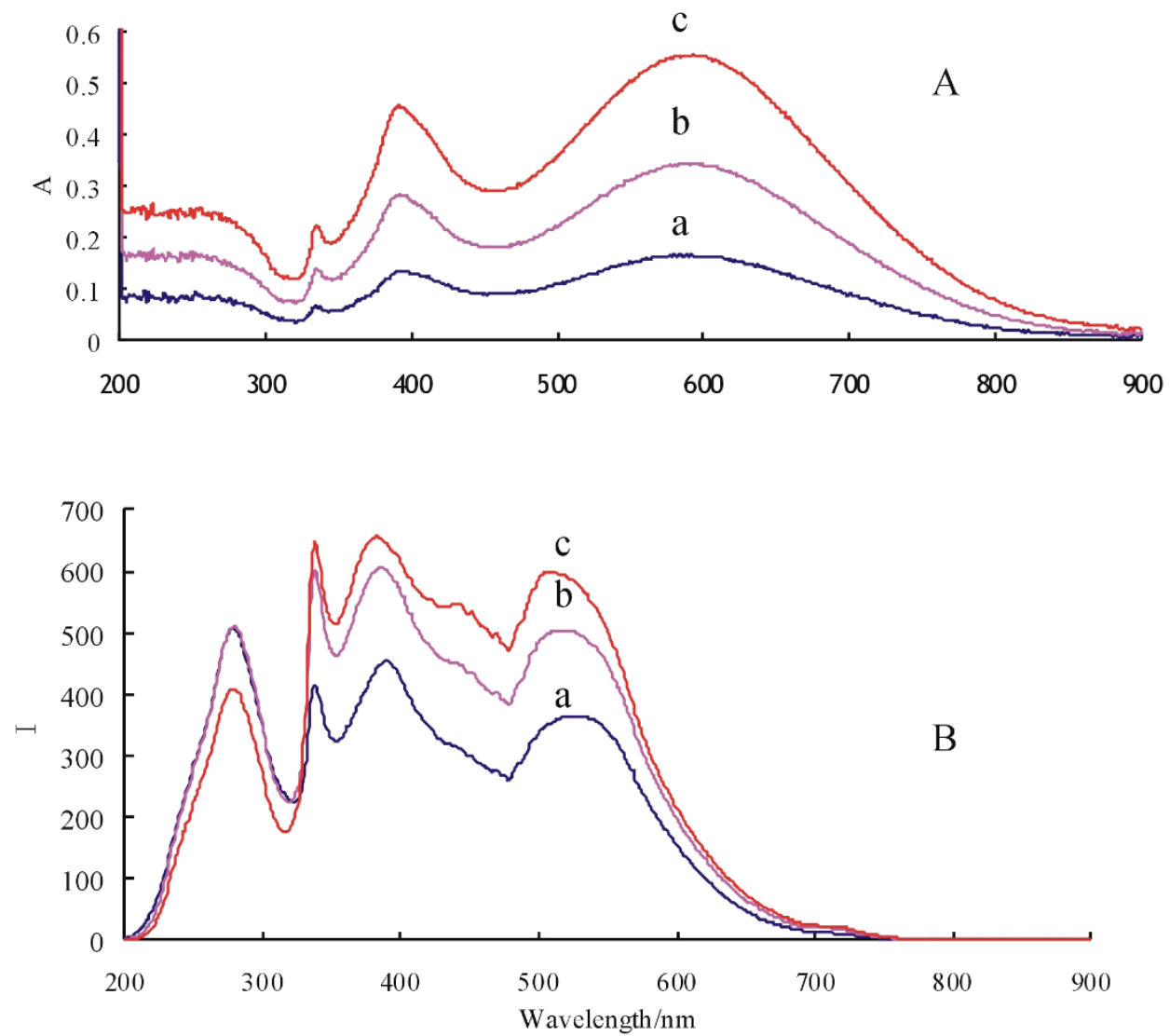

Figure 4 SPR spectra (A) and RRS spectra (B) of AgNPB. (a): $2.5 \times 10-5 \mathrm{~mol} / \mathrm{L}$ AgNPB; (b): 5.0 × 10-5 mol/L AgNPB; (c): $7.5 \times 10-5$ mol/L AgNPB. 
$285 \mathrm{~nm}$ (Fig. 6S,7S). The absorbance increased slowly with the $\mathrm{AgNO}_{3}$ concentration increased in the range of 12.5-100 $\times$ $10^{-6} \mathrm{~mol} / \mathrm{L}$ because $\mathrm{AgCl}$ particles have weak absorption. In the medium of $5.0 \times 10^{-4} \mathrm{~mol} / \mathrm{L} \mathrm{NaCl}$, AgNPB has two SPR absorption peaks at $330 \mathrm{~nm}$ and $530 \mathrm{~nm}$ (Fig. 8S). The absorbance at $530 \mathrm{~nm}$ decreased linearly with the $\mathrm{H}_{2} \mathrm{O}_{2}$ concentration increased in the range of $2-8 \times 10^{-5} \mathrm{~mol} / \mathrm{L} \mathrm{H}_{2} \mathrm{O}_{2}$ that can be used to determine $\mathrm{H}_{2} \mathrm{O}_{2}$.

SERS spectra of AgNP-NaCl- $\mathrm{H}_{2} \mathrm{O}_{2}$ system. SERS technology is very sensitive for the detection of nano-aggregate, and it is very important to choice a suitable molecular probe. Reportedly cationic dye rhodamine $6 \mathrm{G}$ was used as a sensitive SERS probe ${ }^{52}$, but it can interact with AgNP to form aggregate and cannot be used in the analysis of AgNP-NaCl system. Victoria blue B (VBB), used as a SERS probe, had very weak Raman signals in the two systems of $9.25 \times 10^{-5} \mathrm{~mol} / \mathrm{L} \mathrm{AgNP}$ and $9.25 \times 10^{-5} \mathrm{~mol} / \mathrm{L}$ AgNP-2.0 $\times$ $10^{-3} \mathrm{~mol} / \mathrm{L} \mathrm{NaCl}$. With addition of $\mathrm{H}_{2} \mathrm{O}_{2}$, SERS signals enhanced due to the formation of $\mathrm{AgCl}$ and $\mathrm{Ag} / \mathrm{AgCl}$ aggregate and the system exhibited Raman peaks at $224 \mathrm{~cm}^{-1}, 307 \mathrm{~cm}^{-1}, 351 \mathrm{~cm}^{-1}, 564 \mathrm{~cm}^{-1}$, $608 \mathrm{~cm}^{-1}, 772 \mathrm{~cm}^{-1}, 1127 \mathrm{~cm}^{-1}, 1179 \mathrm{~cm}^{-1}, 1309 \mathrm{~cm}^{-1}, 1359 \mathrm{~cm}^{-1}$, $1508 \mathrm{~cm}^{-1}, 1571 \mathrm{~cm}^{-1}, 1647 \mathrm{~cm}^{-1}$ (Fig. 9S). This demonstrated that there are $\mathrm{AgNP} / \mathrm{AgCl}$ aggregates in the system.

\section{Discussion}

Mechanism of autocatalytic oxidization of AgNP. Stabile AgNP in size of $10 \mathrm{~nm}$ was prepared conveniently by $\mathrm{NaBH}_{4}$ reduction of $\mathrm{Ag}^{+}$. When $\mathrm{NaCl}$ was added, $\mathrm{Cl}^{-}$can be adsorbed on the surface of AgNP, and the signals of SPR absorption and RRS are still very weak that indicated no aggregation in the system. After adding $\mathrm{H}_{2} \mathrm{O}_{2}$, small AgNP can catalyze $\mathrm{H}_{2} \mathrm{O}_{2}$ to produce free radicals $\mathrm{HO}$ - with strong oxidation ability, which can oxidize Ag atoms on the surface of AgNP to produce $\left[\mathrm{Ag}^{+}\right]$that is different with the $\mathrm{Ag}^{+}$from $\mathrm{AgNO}_{3}$. The $\left[\mathrm{Ag}^{+}\right]$combined with $\mathrm{Cl}^{-}$to form $[\mathrm{AgCl}]$ molecules which had strong hydrophobic property and then lead to form large $\mathrm{AgNP} / \mathrm{AgCl}$ aggregates that enhanced the scattering signal. Small size $\mathrm{HO} \cdot \mathrm{can}$ penetrate the gap of $[\mathrm{AgCl}]$ molecules to further oxidize $\mathrm{Ag}$ atoms on inner layer of AgNP (Fig. 3), and made AgNP become smaller and its SPR absorption weaker. When $\mathrm{H}_{2} \mathrm{O}_{2}$ increased, the RRS intensity increased linearly due to more big $\mathrm{AgNP} / \mathrm{AgCl}$ aggregates forming, and the SPR absorption decreased linearly due to much less small nanosilver forming. Thus, two new SPR absorption and RRS methods were established to determine $\mathrm{H}_{2} \mathrm{O}_{2}$.

According to the generation mechanism of $\mathrm{HO} \cdot$ and the autocatalytic oxidation mechanism of $\operatorname{AgNP}^{53,54}\left(\mathrm{AgNP}=\mathrm{Ag}_{\mathrm{n}}=\mathrm{Ag}_{\mathrm{m}+2 \mathrm{k}}\right)$, the main reactions of AgNP-NaCl- $\mathrm{H}_{2} \mathrm{O}_{2}$ system are as follows,

$$
\begin{gathered}
\mathrm{Ag}_{\mathrm{n}}+\mathrm{H}_{2} \mathrm{O}_{2}=\mathrm{Ag}_{\mathrm{n}} / \mathrm{HOOH} \\
\mathrm{Ag}_{\mathrm{n}} / \mathrm{HOOH}=\mathrm{Ag} / \mathrm{HOO} \cdot \\
2 \mathrm{Ag}_{\mathrm{n}} / \mathrm{HOO} \cdot=2 \mathrm{Ag}_{\mathrm{n}}+2 \mathrm{HO} \cdot+\mathrm{O}_{2} \\
\mathrm{Ag}_{\mathrm{n}}+\mathrm{HO} \cdot=\mathrm{Ag}_{\mathrm{n}-1} /\left[\mathrm{Ag}^{+}\right]+\mathrm{H}_{2} \mathrm{O} \\
\mathrm{Ag}_{\mathrm{n}-1} / \mathrm{Ag}^{+}+\mathrm{Cl}^{-}=\mathrm{Ag}_{\mathrm{n}-1} / \mathrm{AgCl}
\end{gathered}
$$

In the presence of $\mathrm{NaCl}$, the reducing ability of $\mathrm{Ag}$ was enhanced and made the reaction of $\mathrm{H}_{2} \mathrm{O}_{2}$ oxidize AgNP to form $\mathrm{Ag}_{\mathrm{m}-2 \mathrm{k}} /[\mathrm{AgCl}]_{2 \mathrm{k}}$ complex particles become easily, as the result of the formation of $\mathrm{AgCl}$ particle with low solubility. The total reaction is as follow,

$\mathrm{Ag}_{\mathrm{m}+2 \mathrm{k}}+\mathrm{kH}_{2} \mathrm{O}_{2}+2 \mathrm{kOH}^{-}+2 \mathrm{kCl}^{-}=2 \mathrm{kH}_{2} \mathrm{O}+\mathrm{kO}_{2}+\mathrm{Ag}_{\mathrm{n}-2 \mathrm{k}} /(\mathrm{AgCl})_{2 \mathrm{k}}$

Relationship between the SPR absorption peaks and the RRS peaks of AgNPB. AgNPBs exhibited special optical property that have one sharp out-of-plane quadrupole SPR absorption peak at
$330 \mathrm{~nm}$ (Fig. 4A), one out-of-plane dipole peak at $390 \mathrm{~nm}$, and one broad in-plane dipole peak at $580 \mathrm{~nm}^{54,55}$. The absorbance of the three peaks was linearly increased with AgNPB concentration increased. The study of RRS spectra of nanoparticles in liquid phase shown that, their RRS peaks are closely related with the emission intensity of light source and the SPR absorption peaks ${ }^{56,57}$. The light source of model F-7000 Hitachi fluorescence spectrometer has the strongest emission wavelength at $280 \mathrm{~nm}$ that cause a scattering peak at $280 \mathrm{~nm}$, and the emission intensity weaken as the increase of the wavelength. AgNPB has a sharp scattering peak at $330 \mathrm{~nm}$ which is corresponding to the out-of-plane quadrupole SPR absorption peak (Fig. 4B) that was called as out-of-plane quadrupole RRS peak. AgNPB has a strong RRS peak at $390 \mathrm{~nm}$ that was ascribed to outof-plane dipole SPR absorption, was called as out-of-plane dipole RRS peak. Besides, the in-plane dipole peak at $530 \mathrm{~nm}$ is violetshift $50 \mathrm{~nm}$ compare to its SPR absorption peak because the light source has strong emission at $530 \mathrm{~nm}$. Though the RRS intensity of the three peaks increased with AgNPB concentration increased, they had no linear relationship since the sols exist in multiple scattering.

Analytical features. Under the selected conditions (Fig. 10S-19S), the RRS intensity at $330 \mathrm{~nm}(I)$ of different $\mathrm{H}_{2} \mathrm{O}_{2}$ concentration was recorded, and the working curve between $\Delta I$ and $\mathrm{H}_{2} \mathrm{O}_{2}$ concentration was drawn. The linear range of $\mathrm{AgNP}-\mathrm{NaCl}$ system was $2.0 \times 10^{-8}-8.0 \times 10^{-5} \mathrm{~mol} / \mathrm{L}$, with a regression equation of $\Delta I=$ $71.4 \mathrm{c}-1.6$, a correlation coefficient of 0.9852 , and a detection limit of $8 \times 10^{-9} \mathrm{~mol} / \mathrm{L}$. A $5.0 \times 10^{-7} \mathrm{~mol} / \mathrm{L}, 5.0 \times 10^{-6} \mathrm{~mol} / \mathrm{L}$ and $20 \times$ $10^{-6} \mathrm{~mol} / \mathrm{L} \mathrm{H}_{2} \mathrm{O}_{2}$ were determined five times, and the related standard deviations (RSD) were $4.1 \%, 3.7 \%$ and $3.8 \%$ respectively, this showed that the RRS method has good accuracy. The linear range of $\mathrm{AgNP}-\mathrm{NaCl}-\mathrm{H}_{2} \mathrm{SO}_{4}-\mathrm{FeSO}_{4}$ system was $1.0 \times 10^{-7}-2.5 \times$ $10^{-5} \mathrm{~mol} / \mathrm{L}$, with a detection limit of $2 \times 10^{-8} \mathrm{~mol} / \mathrm{L}$. In the RRS analytical system, the AgNP-NaCl is most sensitive, simple, stabile and low blank (Table 1S), and it was chosen to detect $\mathrm{H}_{2} \mathrm{O}_{2}$ concentration. The SPR methods of the two systems also can be used to determine $\mathrm{H}_{2} \mathrm{O}_{2}$ with low-cost, though they were not as sensitive as RRS methods. According to the procedure, a standard solution containing $20 \times 10^{-6} \mathrm{~mol} / \mathrm{L} \mathrm{H}_{2} \mathrm{O}_{2}$ and various coexistent compounds were examined, with a relative error of less than $\pm 10 \%$. A 100 times of $\mathrm{ClO}_{4}{ }^{-}$and $\mathrm{SO}_{4}{ }^{2-}, 70$ times of $\mathrm{Ca}$ (II) and $\mathrm{Mg}$ (II), 50 times of $\mathrm{Cu}^{2+}, \mathrm{Mo}^{6+}, \mathrm{I}^{-}$, triethanolamine, $\mathrm{Co}^{2+}, \mathrm{NO}_{2}{ }^{-}, 10$ times of $\mathrm{Mn}^{2+}, \mathrm{Br}^{-}$, citric acid, and $2.5 \mathrm{mg} / \mathrm{L}$ HSA did not interfere with the determination. This indicated that the method has good selectivity.

\section{Methods}

Apparatus and reagents. A Model F-7000 fluorescence spectrophotometer (Hitachi Company, Japan) was used to record the RRS spectra by means of synchronous scanning excitation wavelength $\lambda_{\text {ex }}$ and emission wavelength $\lambda_{\mathrm{em}}\left(\lambda_{\mathrm{ex}}-\lambda_{\mathrm{em}}=\Delta \lambda=0\right)$ and the RRS intensity. A Model TU-1901 double beams spectrophotometer (Puxi Tongyong Apparatus Limited Company, Beijing) was used to record the SPR spectra and the SPR intensity. A model JSM-6380LV scanning electron microscope

(Electronic Stock Limited Company, Japan), a model of JEM-2100F field emission transmission electron microscope (Electronic Stock Limited Company, Japan), a model DXR smart Raman spectrometer (Thermo Fisher Scientific Co., Ltd., USA), a moldel SK8200LH ultrasonic reactor (Kedao Company, Shanghai, China), and a model magnetic stirrer (Zhongda Instrumental Plant, Jiangsu, China) were used.

A $1.0 \times 10^{-3} \mathrm{~mol} / \mathrm{L} \mathrm{AgNO}_{3}$ solution, $1 \%(\mathrm{~W} / \mathrm{V})$ sodium citrate solution, $0.05 \mathrm{~mol} /$ $\mathrm{L} \mathrm{NaCl}$ solution, and $1.0 \times 10^{-3} \mathrm{~mol} / \mathrm{L} \mathrm{FeSO}_{4}$ solution were used. A $0.05 \%(\mathrm{~W} / \mathrm{V})$ $\mathrm{NaBH}_{4}$ was prepared freshly. A $0.100 \mathrm{~mol} / \mathrm{L} \mathrm{H}_{2} \mathrm{O}_{2}$ standard solution was prepared as follows: $1.02 \mathrm{~mL} \mathrm{H}_{2} \mathrm{O}_{2}(30 \%)$ was diluted to $100 \mathrm{~mL}$ with water, it was standardized by $\mathrm{KMnO} 4$ procedure, and was diluted to $5.00 \times 10^{-4} \mathrm{~mol} / \mathrm{L}$ before use.

A $1.85 \times 10^{-4} \mathrm{~mol} / \mathrm{L}$ AgNP was prepared as follows: $9.25 \mathrm{~mL} 1.0 \times 10^{-3} \mathrm{~mol} / \mathrm{L}$ $\mathrm{AgNO}_{3}$ and $3.5 \mathrm{~mL} \mathrm{1 \%}$ trisodium citrate were added into a conical flask with stirring and diluted to $40 \mathrm{~mL}$ with water, then $4 \mathrm{~mL} 0.05 \% \mathrm{NaBH}_{4}$ was added slowly with about $15 \mathrm{~min}$, the mixture was diluted to $50 \mathrm{~mL}$, and it can be used after $24 \mathrm{~h}$ to make the $\mathrm{NaBH}_{4}$ decomposing completely. The preparation of AgNP sols was repeated five times, the SPR peak is at $395 \mathrm{~nm}$ with an average absorption value of $2.50 \pm 0.10$, and the sols were stabile within 20 days (Fig.20S). A $1.0 \times 10^{-4} \mathrm{~mol} / \mathrm{L}$ AgNPB was prepared as follows: $40 \mathrm{~mL}$ of water, $500 \mu \mathrm{L} 1.0 \times 10^{-2} \mathrm{~mol} / \mathrm{L} \mathrm{AgNO}_{3}, 1.5 \mathrm{~mL} 6.0 \times$ $10^{-2} \mathrm{~mol} / \mathrm{L}$ sodium citrate, $120 \mu \mathrm{L} 30 \% \mathrm{H}_{2} \mathrm{O}_{2}$, and $200 \mu \mathrm{L} 0.1 \mathrm{~mol} / \mathrm{L} \mathrm{NaBH}_{4}$ were added into a triangle flask in turn with constantly stirring for $15 \mathrm{~min}$. Then heat to 
boil for $5 \mathrm{~min}$ to get rid of the excess $\mathrm{H}_{2} \mathrm{O}_{2}$ and the solution was diluted to $50 \mathrm{~mL}$. All reagents were of analytical grade and the water was highly pure sub-boiling water.

Procedure. A $1.0 \mathrm{~mL} 1.85 \times 10^{-4} \mathrm{~mol} / \mathrm{L}$ AgNP solution, $80 \mu \mathrm{L} 0.05 \mathrm{~mol} / \mathrm{L} \mathrm{NaCl}$ (or adding $80 \mu \mathrm{L} 5.0 \times 10^{-2} \mathrm{~mol} / \mathrm{L} \mathrm{H}_{2} \mathrm{SO}_{4}, 75 \mu \mathrm{L} 1.0 \times 10^{-3} \mathrm{~mol} / \mathrm{L} \mathrm{FeSO}_{4}$ ), and a certain amount of $\mathrm{H}_{2} \mathrm{O}_{2}$ solution were added into a $5 \mathrm{~mL}$ calibrated tube in turn, then diluted to $2 \mathrm{~mL}$ and mixed well. The RRS intensity at $330 \mathrm{~nm}(I)$ was recorded by a fluorescence spectrophotometer with synchronous scanning $\left(\lambda_{\mathrm{ex}}-\lambda_{\mathrm{em}}=\Delta \lambda=0\right)$. A blank $\left(I_{0}\right)$ without $\mathrm{H}_{2} \mathrm{O}_{2}$ was recorded and the value of $\Delta I=I-I_{0}$ was calculated.

1. Ke, J. et al. Dopant-induced modification of active site structure and surface bonding mode for high-performance nanocatalysts: $\mathrm{CO}$ oxidation on cappingfree (110)-oriented $\mathrm{CeO}_{2}: \mathrm{Ln}(\mathrm{Ln}=\mathrm{La}-\mathrm{Lu})$ nanowires. J. Am. Chem. Soc. 135, 15191-15200 (2013).

2. Zhang, S. et al. In-situ studies of nanocatalysis. Acc. Chem. Res. 46, 1731-1739 (2013).

3. Dutta, S. et al. Silver nanoparticle decorated reduced graphene oxide (rGO) nanosheet: a platform for SERS based low-level detection of uranyl ion. ACS Appl. Mater. Interfaces 5, 8724-8732 (2013).

4. Veerakumar, P., Ramdass, A. \& Rajagopal, S. Ruthenium nanocatalysis on redox reactions. J. Nanosci. Nanotechnol. 13, 4761-4786 (2013).

5. Borys, N. J., Shafran, E. \& Lupton, J. M. Surface plasmon delocalization in silver nanoparticle aggregates revealed by subdiffraction supercontinuum hot spots. Sci. Rep. 3, 2090 (2013).

6. Chen, P. et al. Single-molecule fluorescence imaging of nanocatalytic processes. Chem. Soc. Rev. 39, 4560-4570 (2010).

7. Wen, G. Q., Liang, A. H. \& Jiang, Z. L. Functional nucleic acid nanoparticle-based resonance scattering spectral probe. Plasmonics 8, 899-911 (2013).

8. Zhu, Z. et al. Manipulation of collective optical activity in one-dimensional plasmonic assembly. ACS Nano 6, 2326-2332 (2012)

9. Negreiros, F. R. et al. A first-principles theoretical approach to heterogeneous nanocatalysis. Nanoscale 4, 1208-1219 (2012).

10. Fihri, A. et al. Nanocatalysts for Suzuki cross-coupling reactions. Chem. Soc. Rev. 40, 5181-5203 (2011).

11. Chng, L. L., Erathodiyil, N. \& Ying, J. Y. Nanostructured catalysts for organic transformations. Acc. Chem. Res. 46, 1825-1837 (2013).

12. Roldan, C. B. Metal nanoparticle catalysts beginning to shape-up. Acc. Chem. Res. 46, 1682-1691 (2013).

13. $\mathrm{Li}, \mathrm{L}$. et al. Selective synthesis of $\mathrm{Cu}_{2} \mathrm{O}$ nanocrystals as shape-dependent catalysts for oxidative arylation of phenylacetylene. Chemistry 18, 10491-6 (2012).

14. Kalidindi, S. B. \& Jagirdar, B. R. Nanocatalysis and prospects of green chemistry. ChemSusChem. 5, 65-75 (2012).

15. Yao, D. M., Wen, G. Q. \& Jiang, Z. L. A highly sensitive and selective resonance Rayleigh scattering method for bisphenol A based on the aptamer-nanogold catalysis of $\mathrm{HAuCl}_{4}$-vitamine $\mathrm{C}$ particle reaction. RSC Adv. 3, 13353-13356 (2013).

16. Cao, C. et al. Dual enlargement of gold nanoparticles: from mechanism to scanometric detection of pathogenic bacteria. Small 7, 1701-1708 (2011)

17. Mohamed, M. B. et al. Growth mechanism of anisotropic gold nanocrystals via microwave synthesis: formation of dioleamide by gold nanocatalysis. ACS Nano 4 , 2766-72 (2010).

18. Harding, C. et al. Control and manipulation of gold nanocatalysis: effects of metal oxide support thickness and composition. J. Am. Chem. Soc. 131, 538-548 (2009).

19. Yang, P. \& Huo, R. T. Influence of Coupling Agents modification on photocatalysis activity of nano-TiO ${ }_{2}$. J. Chin. Ceram. Soc. 41, 409-415 (2013).

20. Jiang, Z. L. et al. Resonance scattering assay for trace human chorionic gonadotrophin using gold-platinum nanoalloy immunoprobe as catalyst. Acta Chim. Sin. 70, 1748-1754 (2012).

21. Wen, G. Q., Liang, A. H. \& Jiang, Z. L. Functional nucleic acid nanoparticle-based resonance scattering spectral probe. Plasmonics 8, 899-911 (2013).

22. Kung, C. C. et al. Preparation and characterization of three dimensional graphene foam supported platinum-ruthenium bimetallic nanocatalysts for hydrogen peroxide based electrochemical biosensors. Biosens. Bioelectron. 52, 1-7 (2014).

23. Tang, J. et al. In situ amplified electronic signal for determination of lowabundance proteins coupling with nanocatalyst-based redox cycling. Chem. Commun. 49, 1530-1532 (2013).

24. Jiang, Z. L., Qin, H. M. \& Liang, A. H. A new nanocatalytic spectrophotometric assay for cationic surfactant using phosphomolybdic acid-formic acid-nanogold as indicator reaction. Chin. J. Chem. 30, 59-64 (2012).

25. Dong, J. C., Liang, A. H. \& Jiang, Z. L. A highly sensitive resonance Rayleigh scattering method for hemin based on the aptamer-nanogold probe catalysis of citrate- $\mathrm{HAuCl}_{4}$ particle reaction. $R S C \mathrm{Adv}$. 3, 17703-17706 (2013).

26. Lai, W. Z. et al. Preparation and optical properties of triangular silver nanoplates by a dual reduction method. Acta Phys. Chim. Sin. 26, 1177-1183 (2010).

27. Jin, R. C., Cao, Y. W. \& Mirkin, C. A. Photoinduced conversion of silver nanospheres to nanoprisms. Science 294, 1901-1903 (2001).

28. Jiang, Z. L., Zhou, L. P. \& Liang, A. H. Resonance scattering detection of trace melamine using aptamer-modified nanosilver probe as catalyst without separation of its aggregations. Chem. Comm. 47, 3162-3164 (2011).
29. Cooper, W. J., Zika, R. G. \& Petasne, R. G. Photochemical formation of hydrogen peroxide in natural waters exposed to sunlight. Environ. Sci. Technol. 22, $1156-1160$ (1988).

30. Rica, R. \& Stevens, M. M. Plasmonic ELISA for the ultrasensitive detection of disease biomarkers with the naked eye. Nat. Nanotechnol. 7, 821-824 (2012)

31. Slimane, M. et al. Influence of experimental parameters on sonochemistry dosimetries: $\mathrm{KI}$ oxidation, Fricke reaction and $\mathrm{H}_{2} \mathrm{O}_{2}$ production. J. Haz. Mat. 178, 1007-1014 (2010).

32. Wang, Z. H. et al. Graphene-amplified electrogenerated chemiluminescence of CdTe quantum dots for $\mathrm{H}_{2} \mathrm{O}_{2}$ sensing. Luminescence 28, 259-264 (2013).

33. Abbas, M. E. et al. Fluorometric determination of hydrogen peroxide in milk by using a Fenton reaction system. Food Chem. 120, 327-331 (2010).

34. Chai, X. S. et al. Rapid determination of hydrogen peroxide in the wood pulp bleaching streams by a dual-wavelength spectroscopic method. Anal. Chim. Acta 507, 281-284 (2004).

35. Luo, W. et al. Rapid quantitative determination of hydrogen peroxide by oxidation decolorization of methyl orange using a Fenton reaction system. Anal. Chim. Acta 629, 1-6 (2008).

36. Dreaden, E. C. et al. The golden age: gold nanoparticles for biomedicine. Chem. Soc. Rev. 41, 2740-2779 (2012).

37. Song, Y. J., Wei, W. L. \& Qu, X. G. Colorimetric Biosensing Using Smart Materials. Adv. Mater. 23, 4215-4236 (2011).

38. Liu, X. et al. A one-step homogeneous immunoassay for cancer biomarker detection using gold nanoparticle probes coupled with dynamic light scattering J. Am. Chem. Soc. 130, 2780-2278 (2008).

39. Guo, Y. M. et al. Colorimetric detection of mercury, lead and copper ions simultaneously using protein-functionalized gold nanoparticles. Biosen. Bioelectron. 26, 4064-4069 (2011).

40. Liu, J. M. et al. Ultra-sensitive non-aggregation colorimetric sensor for detection of iron based on the signal amplification effect of $\mathrm{Fe}^{3+}$ catalyzing $\mathrm{H}_{2} \mathrm{O}_{2}$ oxidize gold nanorods. Talanta 116, 199-204 (2013).

41. Tripathy, S. K., Woo, J. Y. \& Han, C. S. Highly selective colorimetric detection of hydrochloric acid using unlabeled gold nanoparticles and an oxidizing agent. Anal. Chem. 83, 9206-9212 (2011).

42. Diez, I. \& Ras, R. H. A. Fluorescent silver nanoclusters. Nanoscale 3, 1963-1970 (2011)

43. Zhang, M. \& Ye, B. C. Colorimetric chiral recognition of enantiomers using the nucleotide-capped silver nanoparticles. Anal. Chem. 83, 1504-1509 (2011).

44. Thompson, D. G. et al. Ultrasensitive DNA detection using oligonucleotide silver nanoparticle conjugates. Anal. Chem. 80, 2805-2810 (2008).

45. Li, K. et al. A stable and reproducible nanosilver-aggregation-4-mercaptopyridine surface-enhanced Raman scattering probe for rapid determination of trace $\mathrm{Hg}^{2+}$. Talanta 99, 890-896 (2012).

46. Liu, Y. \& Huang, C. Z. Screening sensitive nanosensors via the investigation on shape-dependent localized surface plasmon resonance of single Ag nanoparticles. Nanoscale 5, 7458-7466 (2013).

47. Wu, Y. G. et al. Nanoparticles assembled by aptamers and crystal violet for arsenic(III) detection in aqueous solution based on a resonance Rayleigh scattering spectral assay. Nanoscale 4, 6841-6849 (2012).

48. Fu, X. B. et al. A label-free thrombin binding aptamer as a probe for highly sensitive and selective detection of lead(II) ions by a resonance Rayleigh scattering method. Analyst 137, 1097-1099 (2012)

49. Mie, G. Beitrage zur optik trüber medien, speziel kolloidaler metallosungen. Ann Phys. 25, 377-445 (1908)

50. Sun, Y. G., Gates, B. \& Mayers, B. Crystalline silver nanowires by soft solution processing. Nano Lett. 2, 165-168 (2002).

51. Jain, P. K., Eustis, S. \& El-Sayed, M. A. Plasmon coupling in nanorod assemblies: optical absorption, discrete dipole approximation simulation, and excitoncoupling model. J. Phys. Chem. B 110, 18243-8253 (2006).

52. Jiang, Z. L. et al. A label-free nanogold DNAzyme-cleaved surface-enhanced resonance Raman scattering method for trace $\mathrm{UO}_{2}{ }^{2+}$ using rhodamine $6 \mathrm{G}$ as probe. Plasmonics 8, 803-810 (2013).

53. Novikov, A. S. et al. Generation of HO- radical from hydrogen peroxide catalyzed by aqua complexes of the group III metals $\left[\mathrm{M}\left(\mathrm{H}_{2} \mathrm{O}\right)_{\mathrm{n}}\right]^{3+}(\mathrm{M}=\mathrm{Ga}, \mathrm{In}, \mathrm{Sc}, \mathrm{Y}$, or La): A theoretical study. ACS Catal. 3, 1195-1208 (2013).

54. Maillard, M., Huang, P. \& Brus, L. Ag nanodisk growth by surface plasmon enhanced photoreduction of adsorbed $\left[\mathrm{Ag}^{+}\right]$. Nano Lett. 3, 1611-1615 (2003).

55. Jiang, P., Li, S. Y. \& Xie, S. S. Machinable long PVP-stabilized silver nanowires. Chem. Eur. J. 10, 4817-4821 (2004)

56. Liang, A. H. et al. Surface plasmon resonance effect of nanogold/silver and its analytical application. Tr. Anal. Chem. 37, 32-47 (2012)

57. Jiang, Z. L. et al. Nanocatalytic resonance scattering spectral analysis. Sci. China Chem. 53, 1049-1054 (2010).

\section{Acknowledgments}

This work supported by the National Natural Science Foundation of China (No. 21267004, $21307017,21367005,21365011)$, the Research Funds of Guangxi Key Laboratory of Environmental Pollution Control Theory and Technology, the Natural Science Foundation of Guangxi (No. 2013GXNSFFA019003, 2013GXNSFAA019046), and the Research Funds of Guangxi Education Department (No. 2013YB234, 2013YB035). 


\section{Author contributions}

G.Q.W. and Y.H.L. performed the experiment and measurement analysis. G.Q.W. and Z.L.J. prepared Fig.1-4. A.H.L. and Z.L.J. contributed to the discussion and measurement analysis. All authors contributed to the preparation of the manuscript and reviewed the manuscript.

\section{Additional information}

Supplementary information accompanies this paper at http://www.nature.com/ scientificreports

Competing financial interests: The authors declare no competing financial interests.
How to cite this article: Wen, G.Q., Luo, Y.H., Liang, A.H. \& Jiang, Z.L. Autocatalytic Oxidization of Nanosilver and Its Application to Spectral Analysis. Sci. Rep. 4, 3990; DOI:10.1038/srep03990 (2014).

This work is licensed under a Creative Commons Attribution 3.0 Unported license. To view a copy of this license, visit http://creativecommons.org/licenses/by/3.0 